\title{
FOXR1 Gene
}

National Cancer Institute

\section{Source}

National Cancer Institute. FOXR1 Gene. NCI Thesaurus. Code C143124.

This gene plays a role in DNA binding and transcriptional regulation. 